investigations in the National Research Council Laboratory at Montreal, until in 1946 he was elected professor of radiotherapeutics in the University of Cambridge. In his own department at Addenbrooke's he started regular joint clinics with physicians, surgeons and specialists in charge of special departments, and these have become an increasingly important factor in integration. His approach is always as a physician using radiation as a method of medical treatment. In research he has ranged widely, but of recent years his topics have included the design and conduct of clinical trials of new methods of treatment of cancer, the chemotherapy of cancer, the radiotherapy of malignant tumours with especial reference to the 30 -million volt synchrotron and the clinical applications of radioactive isotopes. His considerable scientific attainments are matched by his kindness and concern for the well-being of his patients. $\mathrm{He}$ was made C.B.E. in 1951 and elected to the Royal Society in the following year. As regius professor of physic at Cambridge he is well equipped not only scientifically and clinically, but also by local know. ledge of the organization of the University and of the region, to direct the development of the Cam. bridge Medical School.

\section{Athanasius Kircher}

THE magic lantern is said to have been invented by Athanasius Kircher, the date being given variously as 1646,1664 or 1671 . In the Observer exhibition held last summer in London he was featured, along with Lucretius, Ptolemy and Leonardo da Vinci, as "discovering a principle involved in Cinematography", and in a history of the silent film published last year in Germany-"Unsterblicher Film", by Heinrich Fraenkel-he is mentioned as having converted the camera obscura into a magic lantern. In his "History of Light", published in 1772, Joseph Priestley says with reference to Kircher, "we are perhaps, at this day, most obliged to him for his ingenious contrivance of the Magic Lantern... Those who chuse to see Kircher's own drawing of this ingenious instrument will find some very fine ones in his Ars Magna Lucis et Umbrae". Whether or not Kircher did invent the magic lantern has been fully investigated by Dr. P. A. Houston (Sci. Prog., 45, No. 179 ; July 1957); the investigations show that almost certainly Kircher did not invent the magic lantern and deserved the epithets given to him by a writer in the Allgemeine Deutsche Biographie. "I have gone into these works of Kircher in detail," he said, "because it was my purpose to show him as the charlatan he was. He had a many. sided education and great zeal, but only superficial knowledge, and no idea of method; he was a diligent worker, but he was neither reliable nor thorough. He was not the researcher for whom it is sufficient if the experts appreciate his work; what his nature required was the empty admiration of the so-called 'wider circles' and to retain this he stooped to falsification."

\section{World Federation of Scientific Workers}

THE fifth General Assembly of the World Federation of Scientific Workers was held in Holsinki during August 29-September 2. Fifty-three representatives from eighteen countries were present and the delegates included Aeademicians Chou Pei Yuan (China), A. I. Oparin (U.S.S.R.), I. Malek (Czechoslovakia) and Profs. J. D. Bernal and C. F. Powell (Great Britain).
Apart from the discussion of internal affairs of the Federation, there were two symposia on "The Planning of Science" and "Scientific and Technological Training", respectively. The planning of scientific work has now become important in many countries with differing socia] and economic systems. This symposium provided a valuable opportunity for an exchange of ideas and information concerning the practical consequences of planning. The second symposium gave an opportunity for reviewing what had been achieved in this field in a number of countries. Many of the problems of curricula and organization are common to all countries and evidently arise from the rapidity with which science has developed in recent times. The sandwich courses which are being developed in Great Britain are an innovation as yet little known abroad. The symposium served to emphasize what is already well known, namely, that the total number of students undergoing higher education in the U.S.S.R. is very high compared with Great Britain.

Prof. C. F. Powell was elected president of the Federation in succession to Prof. F. Joliot-Curie, and the new vice-presidents are Academician Li Szekwang (China), Academician A. I. Oparin (U.S.S.R.), Prof. C. Sadron (France), Dr. G. P. Nørregård (Denmark) and Prof. J. D. Bernal (Great Britain). After the conclusion of the Assembly, all members were invited to go to Leningrad as the guests of the Union of Higher Educational and Seientific Workers of the U.S.S.R. The thirty-three representatives who went to Leningrad were able to make contact with the scientific institutes of the Academy of Sciences and with departments of the University of Leningrad. Visits to places of historic and artistic interest were also arranged.

\section{Geochemistry}

A syMposium on geochemistry was held in Paris during July 22-24 under the auspices of the International Union of Pure and Applied Chemistry. It was organized by the local chairman, Prof. E. Raguin, and presided over by Prof. T. F. W. Barth with Prof. K. Rankama acting as a secretary. One hundred and fifteen members, representing eighteen countries, were present, and fifty-two papers were read and discussed. The subjects dealt with comprised geochemical aspects of cosmology, distribution of chemical elements, geochemical aspects of rocks and mineral waters, radioactive elements, geochronology, geochemistry of ore deposits and carbonaceous deposits and geochemical prospecting. Prior to the Symposium, on July 20 and 21 , eight members of the Commission on Geochemistry met and discussed current business and plans for the future. A joint meeting of the Commission with representatives of the Geochemical Society and the Geochemical Societies of France and Japan was also held.

The present composition of the Commission on Geochemistry is as follows: President, T. F. W. Barth (Oslo) ; Vice-President, C. W. Correns (Göttingen); Secretury, K. Rankama (Helsinki) ; Other Members, H. S. Brown (Pasadena), C. Burri (Zurich), M. Fleischer (Washington, D.C.), S. I. Tomkeieff (Newcastle upon Tyne), H. C. Urey (Chicago), L. R. Wager (Oxford) and F. E. Wickman (Stockholm); Previously elected observer, G. Carobbi (Florence); Newly elected observers (pending approval by the Union), L. H. Ahrens (Cape Town), C. G. Du Plessis 